Academic City University College - Accra Ghana

Society for Multidisciplinary \& Advanced Research Techniques (SMART) Africa

Tony Blair Institute for Global Change

FAIR Forward - Artificial Intelligence for All - Deutsche Gesellschaft für Internationale Zusammenarbeit (GIZ) GmbH

Accra Bespoke Multidisciplinary Innovations Conference (ABMIC)

\title{
The Effect of Information and Communication Technologies (ICTs) on Academic Libraries in Nigerian Universities
}

Ogala Justin Onyarin \& Okeh Okerierhie Dono

Department of Computer Science

Faculty of Computing

University of Delta

Agbor, Delta State, Nigeria

E-mails

justinoo2001@gmail.com

okehdonokingsley@gmail.com;

Member Proceedings Citation Format

Ogala, J.O. \& Okeh, O.D. (2021): The Effect of Information and Communication Technologies (ICTs)

on Academic Libraries in Nigerian Universities. Proceedings of the Accra Bespoke

Multidisciplinary Innovations Conference. University of Ghana/Academic City University

College, Accra, Ghana. December 2021. Pp 309-318.

www.isteams.net/ghanabespoke2021.

DOI https://doi.org/ 10.22624/AIMS/ABMIC2021-V2-P24 


\title{
The Effect of Information and Communication Technologies (ICTs) on Academic Libraries in Nigerian Universities
}

\author{
Ogala Justin Onyarin \& Okeh Okerierhie Dono
}

\begin{abstract}
A descriptive study was conducted to look into the effects of Information and Communication Technologies (ICTs) on academic libraries in Nigeria universities.. Four research questions guided the study. A review of the related literature was also carried out. The study took place in nine selected Nigerian universities. Survey participants were librarians and library officers from nine state-run university libraries. To collect data, the researchers had used san online survey template and a questionnaire. The information gathered was interpreted with descriptive and inferential statistics. The results indicate that university libraries have differing degrees of ICT infrastructure capacity. The automation of library materials has begun, and database technology has vastly increased information storage and retrieval. Insufficient library funding/financial assistance, as well as inadequate technological infrastructures, was also found. In order to provide efficient resources, any division in such an academic library should indeed be computerized. Governments should prioritize library funding and financial assistance in their budgets. Under their small budgets, management could perhaps emphasize ICT spending..
\end{abstract}

Keywords: ICT, Academic Library, CD-ROM,, Nigerian University.

\section{INTRODUCTION}

This Academic Libraries Survey of Academics was created to look into how academics are publishing, sharing, and using various types of materials in their research and teaching. Academic libraries have placed a greater emphasis on developments in information and communication technologies to establish a baseline for analyzing this survey. Global information is now available due to twenty-first-century information and communication technology, and has an influence on all human endeavours Chisengaa (2000). Academic libraries fail to deliver successful resources due to the exponential development in knowledge and the problems presented by upgrading manually runtime environments. The new information movement opens up new opportunities for the future, with information distributed in a variety of ways. The planet is becoming a knowledge based economy as a result of these capabilities. The reach of knowledge collection, organisation, and distribution is broadened by information and communication technologies (ICTS). These innovations change how libraries navigate, retrieve, store, manipulate, and disseminate information to their guests.

Krubu and Osawaru (2011) noted that academic libraries are those libraries that are primarily located in tertiary institutions; they are developed to facilitate studying, teaching and study processes. Academic libraries are repositories of resources arranged to offer physical, biographical, and academic access to a target audience, as well as a staff trained to deliver resources and programs relevant to that group's knowledge needs. 
Academic libraries use ICTs to enhance facilities, and have a significant impact on teaching, studying, science, and other scholarly and technical practices through better communications and knowledge access. The advent of the internet and technical advances like computer files, web services, CD-ROMs, as well as the emergence of the internet have dramatically improved access to resources. The use of ICTs in information services is commendable, and Rana (2021) maintains that ICT is the path to revamping information resources' progress.

In the field of technology, university libraries need information and communication systems, which require the interconnection of all essential equipment and resources. To ensure the smooth operation of the libraries, ICT infrastructure in the academic and collaboration networks, data, facilities, and human resources are required. Academic libraries have transformed resources and provided access to global information as a result of the accelerated development of information.

\section{REVIEW OF RELATED LITERATURE}

Information and communication technologies (ICTs) have been described in a variety of ways by academics. Information and Communication Technology (ICTs) refers to the facilities for generating, saving, transmitting, and retrieving digital files, according to Ndukwe (2006). They also mentioned that information and communication technology (ICT) is an innovative tool that can support a country's multidimensional growth. Information and Communication Technologies (ICTs) are described by Feather and Sturges (2003) as the use of modern electronic material for the development and storing of useful and meaningful data (information), as well as its dissemination to users via various electronic devices. ICTs are described by Olakulehi (2007) as a set of technologies used in the process of capturing, storing, editing, retrieving, and transmitting information in different ways.

Computers, printers, scanners, photocopiers, telephones, videos, magnetic tape, typewriters, facsimiles, telephones, internet access / e-mail, wire radiophone, local area network (LAN), modern digital radio, website, digital cameras, webcam, and smartcard are among the numerous ICT facilities mentioned by Okoye, (2011) and Olatokun (2007). Information and communication technologies (ICTs) are critical to the modernization of university libraries information management, and yet they have resulted in enormous improvements and transformations of academic field of library and information resources.

The use of ICTs in libraries is also fraught with challenges. Mabawonku (2003), Nwachukwu (2005), and Inyang, \{2015.\} all mentioned the challenges, including epileptic power supply, weak communication; high costs of ICT equipment and peripheral devices. Most academic libraries in Nigeria provide information technology-driven services with the primary goal of facilitating access to scholarly information facilities. But, as a result of the issues addressed, the use of ICTs in Nigerian academic libraries is distinctly average.

\subsection{Statement of the Problem}

Amongst other advantages of ICT in Nigerian university libraries, some libraries continue to struggle with rendering efficient and cost-effective ICT infrastructures. There are a number of issues of ICT recruitment and implementation. A descriptive study was conducted to investigate the effect of ICT on Nigerian universities libraries. Capital investments in hardware, applications, and electricity are some of the impediments. 


\subsection{Objective of the Study}

The study's objectives are as follows:

1. To decide whether or not ICT facilities are available in academic libraries.

2. To assess the degree to which university libraries have been computerized.

3. To assess the advantages of ICTs in university libraries in Nigeria.

\subsection{Research Questions}

To actually guide the study, the following questions were presented.

1. What ICT infrastructure is available in university libraries?

2. To what degree has ICT been used in Nigerian academic libraries?

3. What are the advantages of using digital research activities in university libraries?

4. What are the barriers of using ICT in academics needs?

\subsection{Significance of the Study}

This review should provide extensive information on the acquisition and deployment of information and communication technology services and infrastructure in Nigerian academic libraries. The researchers highlighted emerging shortcomings in the development and deployment of information and communication technology (ICT) and provide strategies that will improve service quality and academic transition in these libraries. The paper also acts as a model for scientists, knowledge administrators, academics, lecturers, and students who want to be more useful to society. as a model for scientists, knowledge administrators, academics, lecturers, and students who want to be more useful to society.

\section{RESEARCH METHODOLOGY}

This study was administered locally to nine participants, including: Abia State University, Uturu, Ambrose Alli University, Ekpoma, Benue State University, Makurdi, Delta State University,, Abraka, Imo State University, Owerri, Kaduna State University, Kaduna, Kwara State University, Ilorin, Kwara State University, Ilorin.

The findings of the nine survey implementations were aggregated for this report. The researchers worked with the participating nine institutions to develop a version of the survey instrument that was used. The common instrument covers topics in several key areas, including: data preservation and management practices infrastructure in University Libraries,, degree of ICT b use in Nigerian academic libraries, the advantages of using digital research activities in university libraries and he barriers to using ICT in academics needs. Due to the survey flow and skip patterns, not all Nigerian academics universities received every question in the survey.

Recruitment methods and response rates varied for each nine participant's implementation. Each nine participant was provided with an institution-specific branded instance of the online survey. The researchers sent personalized email invitations directly from their survey platform on behalf of participating institutions opted to send the email invitations internally using single open access links. 
Table 1: Partticipating Institutions and Respondents

\begin{tabular}{|l|l|l|}
\multicolumn{2}{|l}{ S/N } & \multicolumn{2}{l|}{ Respondents } \\
\hline 1 & Abia State University, Uturu & 10 \\
\hline 2 & Ambrose Alli University, Ekpoma & 10 \\
\hline 3 & Ekpoma, Benue State University, Makurdi & 10 \\
\hline 4 & Benue State University, Makurdi & 10 \\
\hline 5 & Delta State University Abraka & 10 \\
\hline 6 & Imo State University, Owerri & 10 \\
\hline 7 & Kaduna State University, Kaduna & 10 \\
\hline 8 & Kwara State University, Ilorin & 15 \\
\hline 9 & Kwara State University, Ilorin & 15 \\
\hline & Grand Total & 100 \\
\hline
\end{tabular}

In total, 100 participants started the survey across the nine institutions, and 94 of those respondents completed the survey.

\subsection{Analysis of Data}

Research Question 1: What ICT infrastructure is available in university libraries?

Table 2: The available of data preservation and management practices infrastructure in University Libraries

\begin{tabular}{|l|l|l|l|}
\hline S/N & $\begin{array}{l}\text { Data preservation and } \\
\text { management }\end{array}$ & 94 & 100 \\
\hline 1 & Computers & 94 & 100 \\
\hline 2 & Printers & 75 & 79.6 \\
\hline 3 & Scanners & 72 & 76.6 \\
\hline 4 & Photocopiers & 54 & 57.4 \\
\hline 5 & Telephone & 90 & 95.7 \\
\hline 6 & Internet Connection / e-mail & 30 & 31.9 \\
\hline 7 & Modern Digitals Radio & 20 & 21.3 \\
\hline 8 & Website & 40 & 42.6 \\
\hline 9 & Digital Cameras & 70 & 74.5 \\
\hline 10 & CD-ROM & 60 & 63.8 \\
\hline 11 & Multimedia Projector & & \\
\hline
\end{tabular}

All of the ICT services mentioned in Table 2 are accessible to users in the institutional libraries under investigation. Computers and printers are the most popular, with a frequency of 94 or 100 percent. Online links and e-mail are also present in libraries, according to 90 percent of respondents (95.7 percent). Printers, copy machines, and CD'ROMs all won high scores, showing that they are popular in certain repositories. However, websites that are databases for sourcing information that have a frequency of at least 20 or 21.3 percent are not accessible in any of these university libraries, according to the report. 
Research Question 2: To what degree has ICT been used in Nigerian academic libraries?

Table 3: Extent of ICT Usage in the Academic Libraries

\begin{tabular}{|l|l|l|l|}
\hline S/N & ICTs Usage & Frequencies & Percentages \\
\hline 1 & Cataloguing and Classification & 94 & 100 \\
\hline 2 & Storage & 92 & 97.9 \\
\hline 3 & Organization & 91 & 96.8 \\
\hline 4 & Retrieval & 91 & 96.8 \\
\hline 5 & Circulation & 91 & 96.8 \\
\hline 6 & Reference & 91 & 96.8 \\
\hline 7 & Acquisition & 84 & 89.4 \\
\hline 8 & Information Literacy & 47 & 50 \\
\hline 9 & Current awareness services & 40 & 42.6 \\
\hline 10 & Inter-Library Co-operation & 38 & 40.4 \\
\hline 11 & Users' Orientation & 35 & 37.2 \\
\hline 12 & Bibliographic Supervision & $\mathrm{n} / \mathrm{a}$ & $\mathrm{n} / \mathrm{a}$ \\
\hline
\end{tabular}

The scale of ICT use in institutional libraries is shown in Table 3. The table showed that ICT was used to carry out the majority of services, with the exception of bibliographic supervision. Cataloguing and classification had the maximum level of 94 or 100 percent, followed by storage at 92 or 97 percent, and ICT use in establishment, retrieval, circulation, and reference at 91 or $96.8 \%$. Present awareness services and user orientation, on the other hand, earned the lowest ratings, with 38 and 40.4 percent and 35 and 37.2 percent, respectively.

Research Question 3: What are the advantages of using digital research activities in university libraries?

Table 4: Benefits in Academic Libraries

\begin{tabular}{|l|l|l|l|}
\hline S/N & Benefits of digital research & Frequencies & Percentages \\
\hline 1 & Provision of greater access & 92 & 97.9 \\
\hline 2 & Elimination of repetitive routines & 92 & 97.9 \\
\hline 3 & Improved information retrieval & 90 & 95.7 \\
\hline 4 & Improved information marketing & 89 & 94.7 \\
\hline 5 & Save / generate income & 89 & 94.7 \\
\hline 6 & Improved performance & 89 & 94.7 \\
\hline 7 & $\begin{array}{l}\text { Enhancement of academic } \\
\text { researches }\end{array}$ & 89 & 94.7 \\
\hline 8 & Creation of new services & 50 & 53.2 \\
\hline 9 & Retrospective conversion & 50 & 53.2 \\
\hline 10 & Provision of safety measures & 47 & 50 \\
\hline 11 & Formation of library networks & 30 & 31.9 \\
\hline
\end{tabular}

Many of the ICT advantages mentioned in Table 4 have been encountered in the institutional libraries under investigation. Collaboration and the creation of library networks, which were expected to be a significant advantage, were mentioned the least, with just 30 or 31.9 percent of the time. 
Research Question 4: What are the barriers of using ICT in academics needs?

Table 5: Barriers Militating against the Application of ICTs in Academic Libraries

\begin{tabular}{|l|l|l|l|}
\hline S/N & Challenges of ICTs & Frequencies & Percentages \\
\hline 1 & Epileptic power supply & 92 & 97.9 \\
\hline 2 & Shortage of ICT manpower & 92 & 97.9 \\
\hline 3 & Inadequate training & 92 & 97.9 \\
\hline 4 & Inadequate funding & 92 & 97.9 \\
\hline 5 & Few facilities for preservation & 90 & 95.7 \\
\hline 6 & Scarcity of spare parts & 90 & 95.7 \\
\hline 7 & Poor local area network & 90 & 95.7 \\
\hline 8 & Low bandwidth & 90 & 95.7 \\
\hline 9 & Lack of awareness & 47 & 50 \\
\hline 10 & Poor attitude towards ICT & 35 & 37.2 \\
\hline
\end{tabular}

Table 5 above revealed that much more serious obstacles to use ICT services in Nigerian university libraries are unmediated power supply and Inadequate computer literacy, insufficient ICT manpower, and high costs of ICT facilities problems with care and stability Lack of preservation equipment, lack of machine replacement parts, unstable local area network, and insufficient bandwidth are all problems.

\section{DISCUSSION OF RESULTS}

A descriptive study was conducted to investigate determine the effect of Information and Communication Technologies (ICTs) in Nigerian university libraries. This supports Patra's (2008) assertion that the digital revolution, fuelled by ICT innovation, has fundamentally changed academic libraries. ICTs have shifted the way libraries and information services are delivered around the world.

In academic libraries, the use of ICT technology for information storage and retrieval improves information access. This means that library professionals and university library content providers must be qualified in order to guarantee that ICT skills as acquired. This is perpetuated by Robinson (2008) recommendation that brief computer training and retraining sessions be arranged on a regular basis to help librarians and library personnel who may not have the ability to stay current and relevant on tech skills.

The research also revealed the barriers that inhibit librarians from making integration of ICT. Poor funding and unimpressive power source had been cited as the main barriers with the use of ICTs in university libraries by study participants. Esehar (2019) asserted that several of the fundamental issues Nigeria has with major infrastructure services is that energy had to be accessible 24 hours per day. She went on to say that the epileptic aspects of the situation, as well as the frequent power outages that occur without warning, are not conducive to the development of a sustainable ICT system. 
As per the paper, a big issue mostly in implementation of ICTs in university libraries is a lack of resources. Low bandwidth, inadequate connectivity, a negative attitude toward ICT, technical advances, a lack of search expertise, and a lack of knowledge and dedication are some of the other obstacles that prevent libraries from adopting and effectively using ICTs.

\section{CONCLUSION}

From our key findings, the library serves as a repository of resources; in other words, it archives, preserves, and keeps track of resources. The purpose of this research is to look into the effects of ICT on academic libraries in Nigerian universities. Survey participants were librarians and library officers from nine state-run university libraries. Inadequate library funding/financial assistance, as well as inadequate technological infrastructure, were discovered. User needs have already been converted to online status due to the use of ICTs. It also gives teachers, students, and researcher's easier accesses to resources that can help them educate, read, and conduct studies. Learning has shifted from being focused on the teacher to being centered on the students.

\section{RECOMMENDATIONS}

The following are suggested for university libraries in Nigeria to truly benefit from ICT applications.

- Additional funding resources for essential ICT services can be fully utilized.

- User orientation can be stepped up in terms of delivering knowledge literacy to users through lectures, online courses, presentations and conferences.

- To mitigate the threat of repeated power outages, backup generators should be available.

- Any donor organizations, such as the Tertiary Education Fund (TETFUND), must be aggressively sought out for assistance.

- To encourage efficient resources, any section in an actual university must be automated. 


\section{REFERENCES}

1. Carr, D. (2003). Information professions. In J. Feather, \& P. Sturges (Eds.), International encyclopedia of information and library science (2nd ed., pp. 285-293). New York, USA: Routledge.

2. Chisenga, J. (2000). Global Information and libraries in Sub-Saharan Africa. Library Management, 21(4), 178-187. https://doi.org/10.1108/01435120010693997

3. Esehar, N. (2019). Innovation and Development of Information Communication Technology (ICT) in Libraries: A New Dimension in Librarianship. International Journal of Advanced Research, 7(4), 1536-1542. https://doi.org/10.21474/IJAR01/8980

4. Feather, J., \& Sturges, P. (2003). International Encyclopedia of Information and Library Science (2nd ed.). Routledge. [ebook], Available at https://www.taylorfrancis.com/books/mono/10.4324/9780203403303/internationa I-encyclopedia-information-library-science-john-feather-paul-sturges, Retrieved April 7, 2021, from. https://doi.org/10.4324/9780203403303

5. Inyang, N. (2015). The Role of Information and Communication Technology (ICT) in the Provision of Library Services in Akwa Ibom State Eâ Library, Nigeria. International Journal of Academic Research in Business \& Social Sciences, 4(12). https://doi.org/10.6007/IJARBSS/v4-i12/1373

6. Krubu, D. E. (2013). Some Reflections on the Theory of Information Worlds As a Theoretical Framework for Information Behaviour. Mousaion, 31(3), 1-14. Retrieved from http://reference.sabinet.co.za.ezproxy.uwc.ac.za/document/EJC155981

7. Krubu, D., \& Osawaru, K. (2011). (PDF) The Impact of Information and Communication Technology (ICT) in Nigerian University Libraries. [Online] ResearchGate. Available at: < https://www.researchgate.net/publication/267207651_The_Impact_of_Information_ and Communication Technology ICT in Nigerian University Libraries $>$ [Accessed 3 April 2021].

8. Mabawonku, I. (2004). Potentials of Internet Use in Information Provision to Policy Makers in Nigeria. Nigerian Libraries, [online] 35 (2). Available at: < https://www.ajol.info/index.php/ajlais/article/view/26151 > [Accessed 4 April 2021]. https://doi.org/10.4314/jnla.v35i2.26561

9. Ndukwe, E. C. ... (2006) ICT for development: The challenges of meeting the millennium development goals in Africa, Abuja: Nigeria Communications Commission (NCC).

10. Nwachukwu, V. (2005). Information technologies application to libraries in developing countries: The need for caution. [Online] https://scholar.google.com. Available at: $<$ https://scholar.google.com/scholar?cluster=18367272712210925934\&hl=en\&oi= scholarr> [Accessed 9 April 2021].

11. Ojohwoh, R. (2016). The challenges of effective implementation of information and communication technology (ICT) in Polytechnics and Colleges of Education Libraries in Delta State, Nigeria. Educational Research, [online] 07 (04). Available at:< https://www.researchgate.net/publication/326915675_The_challenges_of_effective_ implementation_of_information_and_communication_technology_ICT_in_Polytechnics _and_Colleges_of_Education_Libraries_in_Delta_State_Nigeria > [Accessed 4 March 2021].

12. Okoye, I., (2011). Application of Information Technology in Nigerian special libraries in Owerri urban area. Information Technologist (The), 7 (2). 
13. Olakulehi, F.. (2005). Turkish Online Journal of Distance Education " Journal Turkish Online Journal of Distance Education " Journal " DergiPark. [online] Tojde.anadolu.edu.tr. Available at: < http://tojde.anadolu.edu.tr/todje25/articles-> [Accessed 10 January 2021].

14. Olatokun, W. (2007). Adoption and use of ICTs in Nigeria's manufacturing industry. A preliminary survey. Information Technologist (The), 4 (1).

15. Patra, B. (2008). The Role of Lesotho Academic Libraries in the Attainment of MDGS. Libraries and Information Services towards the Attainment of the UN Millennium Development Goals, 99-114. https://doi.org/10.1515/9783598441257.99

16. Raha, H. (2021). (PDF) The Impact of Information and Communication Technology (ICT) in Nigerian University Libraries. [Online] Research Gate. Available at: < https://www.researchgate.net/publication/267207651 The Impact of Information and_Communication_Technology_ICT_in_Nigerian_University_Libraries $>$ [Accessed 5 February 2021].

17. Rana, R. (2011). Research trends in library and information science in India with a focus on Panjab University, Chandigarh. International Information and Library Review, 43(1), 23-42. https://doi.org/10.1080/10572317.2011.10762877

18. Robinson, M. (2008) Digital nature and digital nurture: Libraries, learning and the digital native. Library Management, 29(1/2), 67-76. https://doi.org/10.1108/01435120810844658 